\title{
PENGEMBANGAN KAPASITAS : STRATEGI INTERNASIONALISASI PENDIDIKAN TINGGI DI INDONESIA
}

\author{
Retno Sunu Astuti ${ }^{1}$
}

\begin{abstract}
Higher education is one of the key factors in the effort to improve the lives and well-being of a nation. The experience of developed countries in Asia showed that the quality of higher education correlated significantly with the increased competence of human resources as a whole which eventually forms a high competence in the global competition. Globalization proactively answered by the governments in various parts of the world through international cooperation in the form of teaching, research, and dedication to the university in the form of the internationalization program. Through descriptive qualitative method enriched by quantitative techniques with intrinsic case study design (intrinsic case study), this research found that the success of internationalization is driven by capacity building supported by horizontal and hands on leadership. Therefore, the leadership of a university is not only an academic but it must be a manager who is able to read the signs of change.
\end{abstract}

Key Words : Internasionalization, capacity building, leadership, higher education PENDAHULUAN

Pendidikan tinggi di Indonesia dewasa ini telah memasuki era baru, suatu era kompetitif yang penuh tantangan karena adanya perubahan cepat dalam globalisasi. Tantangan dan persaingan yang ketat di era global menuntut adanya kualitas sumberdaya manusia yang kompeten dalam menjawab setiap permasalahan sekaligus memanfaatkan kesempatan yang ada. Pengalaman negara-negara lain yang lebih maju di Asia seperti Jepang, Korea Selatan, atau Malaysia menunjukkan bahwa penyelenggaraan pendidikan tinggi yang berkualitas berkorelasi secara signifikan dengan peningkatan kompetensi sumberdaya manusia secara keseluruhan yang pada akhirnya membentuk kompetensi yang tinggi dalam persaingan global. Pendidikan tinggi merupakan salah satu faktor kunci dalam upaya memajukan kehidupan dan kesejahteraan masyarakat suatu bangsa.

Globalisasi sebagai kekuatan ekonomi, politik, dan sosial mendorong pendidikan tinggidi abad ke-21 ke arah keterlibatan internasional yang lebih besar.Modal globaldiinvestasikan secara besar-besaran dalam industri pengetahuan seluruh dunia, termasuk pendidikan tinggi.Investasi ini menunjukkan lahirnya masyarakat pengetahuan, bangkitnya sektor jasa, dan ketergantungan masyarakat pada produk-

\footnotetext{
${ }^{1}$ Dosen pada jurusan Administrasi Publik FISIP UNDIP, sedang menempuh program Doktor Manajemen dan Kebijakan Publik FISIPOL UGM
} 
produkberbasis pengetahuan dan pegawai berpendidikan tinggi guna mendukung pertumbuhan ekonomi (Albatch: 2004:290). Globalisasi secara tesirat tidak dapat disikapi sebagai sebuah konsep yang netral, karena mendatangkan implikasi pergolakan politik, sosial dan ekonomi (Odin dan Mancias dalam Knight;2008:4).Globalisasi bagi pendidikan tinggimelahirkan kolaborasi dan persaingan global antar universitas di tingkat dunia.Tantangan globalisasitersebut secara proaktif dijawabpemerintah di berbagai belahan dunia melalui kerja sama internasionaldalam bentuk pengajaran, penelitian, dan pengabdian universitas. Penyelenggaraankerjasama dalamdimensi internasionaldilakukan melalui berbagai program dan kegiatan dengan mengintegrasikan wawasan internasional atau global ke dalam fungsi utama dari sebuah perguruan tinggi(Jung Cheol Shin and Harman 2009)

Globalisasi juga mendorong insitusi pendidikan tinggi untuk meningkatkan daya saingmenuju universitas kelas dunia (world class university) melalui proses internasionalisasi. Internasionalisasiadalah salah satu cara yang dilakukan oleh suatu negara untuk merespon globalisasi dan meningkatkan daya saing, namundiharapkan tetap menghormati individualitas bangsa(de Wit, 2006:3, Knight dan de Wit, 1997:15).

Sejumlah penelitian (Maringe;2010:25, Dixon,dkk;2013:4) menemukan di negaranegara maju seperti Amerika Serikat, Inggris, Kanada dan Australia yangmemiliki universitas dengan tingkat internasionalisasi tinggi, cenderung mempunyai karakteristik: a) variasi sumber pendapatan, b) turnovers pendapatan tahunan tinggi, c) memberikan kontribusi lebih kuat bagi pembangunan ekonomi lokal dan regional, d) memiliki tenaga kerja yang beragam, dan e) banyak menarik minat staf dan mahasiswa luar negeri.

Elkin,dkk (2005) dalam penelitian yang dilakukan pada 17 universitas di seluruh dunia menyimpulkan pelaksanaan program internasionalisiasi membutuhkandukungan. Dukungan tersebut meliputi: a) pemimpin sebagai inovator dalam memberikan dorongan terjadinya perubahan, b) kemampuan institusi dalam menyediakan sumberdaya dan anggaran yang dibutuhkan dan c) pengembangan dan komitmen staf yang kuat. Sebelas (11) program internasionalisiasi pendidikan yang dimaksud adalah:

1. Internationally focused programs of study (program studi yang fokus pada internasionalisasi). 
2. International institutional links (membangun jaringan institusi di tingkat internasional).

3. Student exchange programs (program pertukaran pelajar).

4. Internationally recognized research activity (kegiatan riset yang diakui secara internasional).

5. International research collaboration (kerjasama riset internasional).

6. Staff interaction in international context (interaksi staf dalam lingkungan/konteks internasional).

7. Support for internationalstudents (dukungan untuk mahasiswa internasional).

8. Attendance to international students (kehadiran mahasiswa-mahasiwa internasional).

9. Postgraduate international students (mahasiswa internasional pascasarjana).

10. Undergraduate internationalstudents (mahasiswa sarjana internasional).

11. Staff exchange programs (program pertukaran staf).

Dixon (2013:20-21) dan Mc Kellin (dalam Elkin;2005:320) menyebutkan sejumlah keuntungan internasionalisasi yaitu : 1) peningkatan pengakuan lembaga, 2) memasuki pasar baru yang kompetitif, 3) meningkatkan jaringan kerjasama penelitian di tingkat internasional, 4) memberikan pengalaman sebagai bekal kepada mahasiswa dalam memasuki pasar global, 5)membangun jembatan dalam mendapatkan akreditasi internasional, 6) meningkatkan kapabilitas staf dalam mengembangkan ketrampilan, ilmu pengetahuan dan bidang keahlian yang dimiliki dan 7) membekali lulusan memasuki dan bersaing di dalam pasar tenaga kerja global maupun pasar dalam arti luas.

Pelaksanaan internasionalisasi pendidikan tinggibagi negara-negara berkembang lebih berorientasi pada tujuan budaya dan akademik yaitu memperbaiki kualitas dan memecahkan masalah yang terkait dengan belum terpenuhinya tuntutan akan pendidikan yang bermutu (Knight:2008). Tujuan negara-negara berkembang dalam melaksanakan internasionalisasi tersebut sejalan dengan kebijakan internasionalisasi di Indonesia yang tertuang dalam Strategi Jangka Panjang Pendidikan Tinggi. Dalam Rencana Strategis Pendidikan Nasional 2010-2014 dan Rencana Strategis Kementerian Riset,Teknologi dan Pendidikan Tinggi 2015-2019 dinyatakan bahwa Internasionalisasi pendidikan tinggi dipandang sebagai sarana untuk meningkatkan daya saing nasional, 
yang diukur melalui peringkat internasional universitas duniasebagai salah satu pedoman evaluasi kinerja pendidikan tinggi. Oleh karena itu setiap universitas diharapkan untuk berperan aktif.

Sejalan dengan hasil penelitian terdahulu maka penelitian ini mengungkap peran pengembangan kapasitas dalam internasionalisasi pendidikan tinggi di Indonesia.

\section{METODE}

Penelitian ini dilakukan dengan strategi deskriptif kualitatif yang diperkaya dengan teknik kuantitatif melalui data sekunder. Sejalan dengan tipe desain studi kasus yang dikemukakan oleh Denzin (2009:301) penelitian ini menggunakanstudi kasus intrinsik (intrinsic case study) karena lebih bersifat eksploratif dimana masing-masing kasus memiliki keunikannya sendiri.Kasus internasionalisasi pendidikan tinggi yang dilaksanakan oleh perguruan tinggi diungkap lebih dalam dan cermat baik program, aktivitas dan proses yang berlangsung.Lokasi penelitian adalah PTN dan PTS di Indonesia yang telah melaksanakan internasionalisasi, masing-masing secara purposive diwakili oleh fakultas dan universitas itu sendiri.

Teknik pengumpulan data untuk mengungkap masing-masing kasus sangat bervariasi, berfungsi juga sebagai teknik triangulasi yang meliputi : wawancara mendalam, daftar pertanyaan, analisis data sekunder, penelusuran website, penelusuran berita di media cetak terhadap topik yang dianggap relevan dan terlibat langsung dalam rintisan kerjasama dan inisiasi program internasionalisasi.

\section{HASIL PENELITIAN}

Internasionalisasi pendidikan tinggi di Indonesia secara implisit tertuang dalam Pembukaan UUD 1945 alinea 4 yang menyatakan, bahwa "negara ikut serta dalam menjaga ketertiban dunia". Atas dasar ketentuan tersebut, politik luar negeri Indonesia menganut prinsip bebas dan aktif untuk kepentingan bangsa. Prinsip kebebasan ini dapat dimaknai sebagai keterbukaan Indonesia untuk berpartisipasi aktif dalam menjalin kerjasama dengan berbagai bangsa, negara dan organisasi-organisasi internasional.

Landasan internasionalisasi pendidikan tinggi di Indonesia yang dirumuskan dalam Panduan Penyusunan Proposal Hibah Kerjasama Internasional Kementerian Pendidikan Nasional Republik Indonesia menyebutkan bahwa : 
1. Indonesia memandang pendidikan tinggi adalah proses pemuliaan manusia, sehingga pendidikan tinggi tidak diklasifikasikan sebagai barang komersial (profitable goods) yang dapat diperdagangkan.

2. Internasionalisasi pendidikan tinggi di Indonesia diselenggarakan untuk mendukung pembentukan masyarakat intelektual dunia yang memiliki solidaritas dan kesepahaman dalam menjaga dan meningkatkan perdamaian dunia melalui kerjasama dan mobilitas akademik lintas negara.

3. Dalam mempromosikan kerja sama internasional yang produktif dan sinergis dengan negara-negara lain di dunia, maka pendidikan tinggi Indonesia harus tetap menjaga dan memperkuat identitas, budaya dan karakter nasional agar nilai-nilai kebhinekaan atau keragaman sistem pendidikan tinggi di negara-negara lain dapat diinternalisasi secara cerdas dan tidak sekedar larut dalam berbagai pengaruh global (Kemdiknas;2011:1)

Internasionalisasi pendidikan tinggi di Indonesia ditandai dengan meningkatnya jumlah kerjasama PTDN dengan PTLN dalam bentuk pertukaran dosen, mahasiswa dan staf serta banyaknya tawaran akreditasi dari lembaga pendidikan regional maupun internasional seperti Asian University Network (AUN), Assosiation of Southeast Asia Institute of Higher Learning (ASAIHL) dan Standart International Organization (ISO).

Secara kelembagaan upayainternasionalisasi dalam merespon globalisasi yang dilakukan pemerintah Indonesia adalah dengan menyelenggarakan program-program beasiswa bagi mahasiswa luar negeri seperti program Darmasiswa dan Kemitraan Negara Berkembang (Kemendiknas). Sejumlah mahasiswa internasional didukung dengan biaya kuliah swasta untuk mengikuti program-program seperti twinning atau double degreeserta regular degreeseperti yang dilakukan oleh Universitas Gadjah Mada (UGM) dengan membukakelas internasional. Sedangkan beberapa universitas mengadakan kerjasama melalui pertukaran pelajar (Soejatminah;2009:73)

Pemerintah melalui Direktorat Pendidikan Tinggi dalam mendukung kegiatan internasionalisasi bagi staf akademik dan staf manajemen yang bertujuan meningkatkan kualitas dan perspektif global dilakukan melalui konferensi/seminar, pertukaran/kunjungan, riset dan penelitian lanjutan. Inisiatif ini didukung oleh program bernama Program Academic Recharging (PAR) A, B, dan C (Antara). PAR A adalah kerjasama dalam bidang manajemen program pascasarjana yang diikuti oleh staf 
manajemen jurusan pascasarjana. PAR B bertujuan mempertajam keterampilan akademik para akademisi senior/pengajar senior dengan menjalankan kegiatan seperti penulisan akademik untuk dijadikan buku atau jurnal internasional.PAR $\mathrm{C}$ bertujuan untuk menciptakan staf akademik bergelar doktor dan kerjasama riset.

Bentuk-bentuk beasiswa lainnya, seperti sandwich program dan twinning tersedia pula bagi para akademisi dari institusi publik maupun swasta sejak tahun 2008. Sandwich program memberikan kesempatan kepada mahasiswa program doktor untuk mengadakan kegiatan-kegiatan di universitas luar negeri seperti analisis laboratorium, studi literatur, dan short course selama lebih-kurang empat bulan untuk meningkatkan kualitas mereka. Sedangkan twinning program diperuntukkan bagi mahasiswa jenjang master, dengan cara mengikuti kuliah di dalam dan di luar negeri. Pada skala nasional, terdapat lima negara utama yang dijadikan orientasi beasiswa, yakni Australia, Malaysia, Jepang, Inggris dan Belanda.

Internasionalisasi di beberapa universitas di Indonesia pada umumnya dilakukan dalam berbagai bentuk kegiatan seperti pelatihan studi bahasa asing, internasionalisasi kurikulum melalui program pemindahan kredit (credit transfer system), penyelenggaraan program double degree/joint degree, program kembaran, pertukaran staf dan mahasiswa, kunjungan dosen dan pakar, kerjasama riset internasional, bantuan teknis, dan mahasiswa internasional (BKLN,2010).

Penelusuran website di berbagai Perguruan Tinggi Negeri (PTN) maupun Perguruan Tinggi Swasta (PTS) menunjukan adanya variasi dalam melaksanakan program internasionalisasi. PTN dan PTS yang masuk dalam rangking WCU (World Class University) antara lain ITB (www.itb.ac.id), UNDIP (www.undip.ac.id), UB(www.ub.ac.id), UGM (www.ugm.ac.id), UI (www.ui.ac.id) dan Gunadarma (www.gunadarma.ac.id) yang menunjukkan telahmelakukan internasionalisasi di bidang penelitian, pendidikan dan pengabdian kepada masyarakat. PTN dan PTS yang tidak masuk dalam rangking WCU seperti Universitas Parahiyangan (www.unpar.ac.id), Universitas Ahmad Dahlan (www.uad.ac.id), Universitas Surabaya (www.ubaya.ac.id), Universitas Dian Nuswantoro (www.udinus.ac.id) melakukan internasionalisasi lebih mengarahpada bidang pendidikan baik degree maupun non degree program melalui program internasionalisasi kurikulum, studi bahasa asing, sistem transfer kredit, rekrutmen mahasiswa asing untuk mengikuti kuliah purna waktu dan/atau program 
khusus, internship internasional bagi mahasiswa dan fakultas, kunjungan studi internasional oleh mahasiswa dan fakultas, joint degree, double degree, sistem penyetaraan studi dan gelar, dan pertukaran mahasiswa internasional,serta mengundang dosen tamu internasional.

Universitas Gadjah Mada di hampir seluruh fakultas telah melakukan internasionalisasi, dengan program S1 yang menonjol antara lain Fakultas Kedokteran dan Fakultas Ekonomika dan Bisnis (FEB). Adapun program yang dilakukan adalah pertukaran mahasiswa dan staff, menyelenggarakan kelas internasional, mengembangkan riset dan kerjasama internasional, dan mengembangkan kultur dan suasana kampus yang mendukung internasionalisasi melalui kegiatan interkultural. Sedangkan untuk program S2 antara lain Program Studi Magister Sistem Teknik (MST), Magister Perencanaan Pengelolaan Pesisir dan Daerah Aliran Sungai (MPPDAS) Fakultas Geografidan Magister Sistem Teknik Transportasi (MSTT) Fakultas Teknik. Adapun program yang dilakukan untuk S2 tekanannya pada program kembaran dan double degree program, kerjasama riset internasional, interaksi staf dalam lingkungan/konteks internasional, dukungan untuk mahasiswa internasional, kehadiran dalam konferensi internasional, dan mahasiswa internasional pascasarjana.

Fakultas Geografi Universitas Gadjah Mada dalam pelaksanaan internasionalisasi telah melakukan berbagai kerjasama baik joint research, student \& lecture exchange, maupun double degree programdengan berbagai universitas di luar negeri antara lain dengan University of Cologne Germany, Radboud University of Nijmegen,University of Paris 1 Pantheon Sorbonne Prancis.Menurut Head of Bureau of International Affairs Fakultas Geografi UGM, jika dilihat dari jumlah kerjasama dalam program pertukaran mahasiswa dan dosen maka perbandingan jumlah yang dikirim ke luar negeri jauh lebih besar dibandingkan dengan jumlah mahasiswa luar negeri yang ke Fakultas Geografi. Kondisi ini tidak bertentangan dengan tujuan utama pelaksanaan kerjasama luar negeri Fakultas Geografiyaitu untuk meningkatan kualitas pengajaran dan penelitian, sehingga jumlah mahasiswa asing tidak menjadi prioritas.

Pandangan tersebut dia atas sejalan dengan pandangan Shaha Ghafur (2010) yang mengatakan bahwa kegiatan kerjasama internasional di Indonesia sebagai respon terhadap internasionalisasi secara normatif bertujuan untuk meningkatkan kualitas pendidikan tinggi, meskipun dalam praktek di lapangan internasionalisasi ternyata tidak 
selamanya berkomitmen kuat kepada mutu pendidikan dankurang memberikan hasil yang diharapkan.

Departemen Pendidikan dan Kebudayaan Nasionalberdasarkan Peraturan Presiden Republik Indonesia Nomor 13 Tahun 2015 yang berganti nama menjadi Kementerian Riset, Teknologi dan Pendidikan Tinggi dalam rangka internasionalisasi telah menentukan target pencapaian peringkat world class university yang dituangkan dalam Renstra Kementerian Riset, Teknologi dan Pendidikan Tinggi 2015-2019. Apabila dilihat target peringkat perguruan tinggi dunia yang hendak dicapai maka jumlah Perguruan Tinggi yang masuk TOP 500 terbaik dunia versi THES/QS belum dapat dicapai (lihat Tabel.1.)

Tabel. 1

Perkembangan Peringkat World Class University 8 Universitas Negeri Di Indonesia Tahun 2009-2015

\begin{tabular}{|c|c|c|c|c|c|c|c|c|}
\hline TAHUN & UGM & UI & ITB & IPB & UNAIR & UNDIP & UB & ITS \\
\hline $\mathbf{2 0 0 9}$ & 250 & 201 & 351 & 550 & 450 & 550 & 550 & 650 \\
\hline $\mathbf{2 0 1 0}$ & 321 & 236 & 425 & 525 & 550 & 650 & 650 & 650 \\
\hline $\mathbf{2 0 1 1}$ & 342 & 217 & $451-500$ & $600+$ & $551-600$ & $601+$ & $601+$ & $601+$ \\
\hline $\mathbf{2 0 1 2}$ & $401-450$ & 273 & $451-500$ & $601+$ & $601+$ & $601+$ & $601+$ & $601+$ \\
\hline $\mathbf{2 0 1 3}$ & $501-550$ & 309 & $461-470$ & $701+$ & $701+$ & $701+$ & $701+$ & $701+$ \\
\hline $\mathbf{2 0 1 4}$ & $551-600$ & 310 & $461-470$ & $701+$ & $701+$ & $701+$ & $701+$ & $701+$ \\
\hline $\mathbf{2 0 1 5}$ & $551-600$ & 358 & $431-440$ & $701+$ & $701+$ & $701+$ & $701+$ & $701+$ \\
\hline
\end{tabular}

Sumber: Diolah dari QS, 2009-2015

Peneliti menduga faktor pendorong tidak tercapainya target yang ditentukantidak sejalan dengan kapasitas yang dimiliki oleh universitas di Indonesia.

\section{PEMBAHASAN}

Pengembangan kapasitas adalah suatu proses untuk meningkatkan kemampuan orang, organisasi atau sistem untuk mencapai maksud dan tujuan yang telah ditetapkan. Pengembangan kapasitas dapat dilihat sebagai suatu proses untuk melakukan atau menggerakan perubahan di berbagai tingkatan baik individu, kelompok, organisasi dan sistem guna meningkatkan kemampuan penyesuaian diri dari orang dan organisasi sehingga mereka merespon lingkungan yang selalu berubah. Dengan demikian pengembangan kapasitas adalah menciptakan organisasi pembelajaran.

Pengembangan kapasitas dalam konsep GTZ (2005:13) adalah suatu proses untuk meningkatkan kemampuan individu, kelompok, organisasi atau masyarakat untuk (i) menganalisis lingkungan mereka, (ii) mengidentifikasi masalah-masalah, kebutuhan, 
isu-isu dan peluang, (iii) memutuskan strategi untuk mengatasi masalah-masalah, isuisu dan kebutuhan tersebut dan memanfaatkan peluang yang relevan, (iv) merancang sebuah rencana tindak, dan (v) mengumpulkan dan mempergunakan secara efektif dan atas dasar sumber daya yang berkelanjutan untuk melaksanakan, memantau dan mengevaluasi rencana-rencana tindak tersebut, dan (v) mempergunakan umpan balik untuk pembelajaran. Pengembangan kapasitas akan lebih efektif apabila berlangsung pada tiga tingkatan yaitu sistem, lembaga dan individu dalam organisasi. Ketiga tingkatan tersebut salaing bergantung, perubahan pada satu tingkatan akan memiliki dampak pada tingkatan yang lain.

Sedangkan menurut Grindle (1997:1-28) pembangunan kapasitas merupakan serangkaian srategi yang ditujukan untuk meningkatkan efisiensi, efektivitas dan responsivitas dalam rangka meningkatkan kinerja dengan memusatkan perhatian kepada dimensi (1) pengembangan sumberdaya manusia, (2) penguatan organisasi, dan (3) reformasi kelembagaan. Terdapat banyak faktor yang mempengaruhi program pengembangan kapasitas, namun dalam internasionalisasi pendidikan tinggi di Indonesia peneliti menemukan faktor kunci adalah kepemimpinan. Faktor conductive leadership merupakan salah satu hal yang paling mendasar dalam mempengaruhi insiasi dan kesuskesan program pengembangan kapasitas personal dalam kelembagaan sebuah organisasi(Riyadi;2006:20). Dalam konteks internasionalisasi lingkungan universitas, harus terus menerus didorong sebuah mekanisme kepemimpinan yang dinamis sebagaimana yang dilakukan oleh sektor swasta. Hal ini karena tantangan ke depan semakin berat dan juga realitas keterbatan sumberdaya yang dimiliki universitas. Kepemimpinan kondusif yang memberikan kesempatan luas pada setiap elemen universitas dalam menyelenggarakan internasionaliisasi.

Hasil penelitian menunjukan bahwa universitas yang berhasil melakukan inisisasi berbagai program internasionalisasi ditopang kepemimpin yang tidak hanya cakap dalam mengelola sebuah universitas tetapi juga seorang pemimpin yang mempunyai komitmen nyata dalam memahami perubahan.Pemimpin tersebut mempunyai ciri-ciri:

- Memiliki kemampuan untuk menyederhanakan kerumitan kebijakan internasionalisasi ke dalam aksi yang lebih sederhana dan mudah dipahami oleh berbagai pihak terkait. Kerumitan kebijakan dapat melahirkan stagnasi dalam 
inisiasi program yang berdampak pada terhambatnya inovasi dan kreasi para pelaksana.

- Mampu memberi penghargaan terhadap setiap pencapain target yang telah ditentukan. Penghargaan tidak harus dalam bentuk imbalan material tetapi dapat juga dalam bentuk pengakuan atas prestasi yang dicapai karena penghargaan merupakan bentuk apresiasi pemimpin terhadap sebuah capaian.

- Mampu menjadi agen perubahan yang menggerakan dan mendorong dalam memecahkan permasalahan yang dihadapi berbagai pihak yang terlibat dalam perencanaan, pelaksanaan dan monitoring program. Sebagai agen perubahan pemimpin harus mampu bersinergi sehingga lebih mudah melakukan perubahan. Kemampuan melakukan mobilisasi atas kekuatan sinergi yang dibangunnya akan melahirkan perubahan. Internasionalisasi sebagai respon globalisasi mesyaratkan kesediaan dan kemampuan melakukan perubahan cara berfikir, bertindak dan mengambil keputusan.

- Mampu membangun, mengembangkan dan memelihara networking dengan berbagai pihak terkait. Networking dalam pelaksanaan internasionalisasi melalui aliansi strategis adalah suatu keharusan, karena mengembangkannetworking bermakna: 1)berbagi ide dan informasi untuk saling belajar terhadap keminatan yang sama, dan 2)menyatukan pengalaman dan sumber daya para pihak untuk meningkatkan impak positif baik yang bersifat kolektif maupun individual. Terbangunya networking yang baik memberikan manfaat dalam : 1)membangunan rasa percaya diri diantara para pihak yang terlibat dalam kerjasama, 2)meningkatkan kerjasama dan koordinasi baik di tingkat universitas maupun di tingkat nasional, 3) memberi pengakuan atas keberhasilan suatu program berbasis budaya lokal, 4)meningkatkan aktivitas dan sinergitas program.

- Mampu mengkomunikasikan gagasan internasionalisasi sebagai kebutuhan institusi. Pemimpin yang berhasil mengkomunikasikan gagasannya adalah pemimpin yang horizontal dan hands on (Kertajaya;2013:38). Horizontal berarti memperlakukan bawahan sebagai teman, sikap ini untuk mendapatkan dukungan atas gagasan yang disampaikan. Hands on berarti mau turun tangan ke lapangan dan bersedia membantu menggerakan tim di lapangan. Pola komunikasi ini merupakan bagian dari perubahan. 


\section{PENUTUP}

\section{Kesimpulan}

Internasionalisasi pendidikan tinggi di Indonesia diselenggarakan untuk mendukung pembentukan masyarakat intelektual dan menyiapkan mahasiswa memasuki pasar global berlandasakan multikulturalime telah mengalami transformasi dan diinisiasi dalam berbagai program. Universitas yang berhasil menyelenggarakan berbagai variasi program internasionalisasi didukung oleh pemimpin yang mempunyai komitmen terhadap perubahan, pengembangan dan pencapaian target internasionalisasi secara berkesinambungan dan institusi yang didukung oleh staf dan sumberdaya anggaran yang memadai. Praktek penyelenggaraan internasionalisasi di banyak universitas belum didukung oleh conductive leadership yang berkomitmen terhadap internasionalisasi sehingga target pencapaian rangking World Class University tidak tercapai dengan baik.

\section{Rekomendasi}

Internasionalisasi bukan merupakan tujuan tetapi cara atau alat agar universitas di Indonesia sejajar dengan universitas lain di dunia. Internasionalisasi membutuhkan pemimpin yang mampu merespon perubahan dan tuntutan jaman oleh karena itu universitas perlu membangun kepemimpinan dengan berbagai syarat kemampuan yang membutuhkan kompetensi seorang pemimpin. Tanggungjawab pemerintah adalah menyusun regulasi syarat-syarat pemimpin universitas yang mampu beradaptasi dengan cepat terhadap perubahan yang ditimbulkan oleh gelombang globalisasi dalam wujud program-program internasionalisasi. Pemimpin yang mampu merealisasi target-target yang direncanakan pemerintah dalam mencapai rangking world class university.

\section{DAFTAR PUSTAKA}

Creswell,John W, 2010, Research Design Pendekatan Kualitatif, Kuantitatif dan Mixed (terj), Pustaka Pelajar, Yogyakarta

De Wit, H. (2006,January). Quality assurance of internationalization. Paper presented at the Osaka Conference on Internationalization of Universities, Osaka, Japan. CT: Greenwood Press.

Dixon,R, Slanickova,D and Warwick P,2013, Business School Partnerships for Globalization, Journal of Teaching in International Business, 24 (3-4).pp. 198213, 2013, Durham University Library, UK 
Elkin, Graham; Devjee, Faiyas; Farnsworth, John, 2005, Visualising TheInternationalisation of Universities, International Journal of Educational Management, Vol. 19 No 4, Tahun 2005, pp 318 - 329

Foskett, Nick, 2010, Global Market, National Challenges, Local Strategies : The Strategic Challenge of Internazionalization dalam Globalization and Internazionalization in Higher Education, Theoritical, Strategic and Management Perspective, Pindar NZ, Auckland, New Zealand

Ghafur, Hanif Saha, 2009, Manajemen Mutu, Penjaminan dan Internasionalisasi Perguruan Tinggi di Indonesia, UI-Press, Jakarta

Foskett, Nick, 2010, Global Market, National Challenges, Local Strategies : The Strategic Challenge of Internazionalization dalam Globalization and Internazionalization in Higher Education, Theoritical, Strategic and Management Perspective, Pindar NZ, Auckland, New Zealand

Ghafur, Hanif Saha, 2009, Manajemen Mutu, Penjaminan dan Internasionalisasi Perguruan Tinggi di Indonesia, UI-Press, Jakarta

Grindle,M.S (Ed), 1997, Getting Good Governance : Capacity Building in The Public Sector of Developing Country, MA:Harvard Institute for International Development, Bostong

Jung Cheol Shin \& Grant Harmant, New Challenges for Higher education : Global and Asia-Pacific Perspective, Asia Pacific Education Review, Education Research Institute, Seoul National University, Seoul, Korea, 2009, p.3, Published on line, 24 April 2009.

Knight,Jane, 2007, Internationalization: Concepts, Complexities and Challenges, dalam International Handbook of Higher Education, Springer

Maringe,Felix and Foskett, Nick,2010,Introduction : Globalization and Universities dalamGlobalization and Internazionalization in Higher Education, Theoritical, Strategic and Management Perspective, Pindar NZ, Auckland, New Zealand

Riyadi,Soeprapto, 2006, Pengembangan Kapasitas Pemerintahan Daerah Menuju Good Governance, Jurnal Ilmiah Administrasi Publik, Volume IV, FIA UNIBRAW, Malang

Soejatminah,Sri, 2009, Internationalisation of Indonesian Higher Education: A Study From The Periphery, Asian Social Science, Vol.5, No.9, Sepetember 2009 